\title{
Arti Pentingnya Toleransi Antar Agama Dalam Persatuan Dan Kesatuan Bangsa Indonesia
}

\author{
Nine Wahyu Agustina \\ IIK STRADA INDONESIA \\ Ninewahyu7@gmail.com
}

\begin{abstract}
ABSTRAK
Toleransi beragama adalah sikap untuk yang saling menerima dan keterbukaan terhadap adanya umat dengan agama yang beragama. Tidak peduli terhadap agama apa yang dianut, setiap orang selayaknya dapat saling menghargai satu dengan yang lain. Tujuan dari toleransi beragama yaitu untuk membuat suasana atau situasi yang dan harmonis serta meningkatkan persatuan dan kesatuanBangsa indonesia merupakan Negara multicultural dengan berbagai keragaman antara lain suku,ras,bahasa,dan juga agama. Keberagaman ini merupakan asset bangsa Indonesia yang harus dijaga dan rawat bersama.keberagaman dalam beragama merupakan sebuah kenyataan yang tidak dapat dihindari. Sehingga setiap umat beragama mempunyai kewajiban untuk mengakui sekaligus menghormati agama lain tanpa membeda-bedakan,seperti makna "Semboyan Bhineka Tunggal Ika yaitu berbeda tetapi tetap satu jua.
\end{abstract}

\section{Kata kunci : Toleransi ,Antar agama, sikap, persatuan kesatuan bangsa Indonesia}

\section{Latar Belakang}

Toleransi adalah sikap menghargai perbedaan agama, suku, etnis, pendapat, sikap, dan tindakan orang lain yang berbeda dari dirinya ,dalam masyarakat berdasarkan pancasila terutama sila pertama ,bertaqwa kepada Tuhan menurut agama dan kepercayaan masingmasing adalah mutlak. Semua agama menghargai manusia maka dari itu semua umat beragama juga wajib saling menghargai .Dengan demikian antar umat beragama yang berlainan akan terbina kerukunan hidup dan menciptakan persatuan dan kesatuan.tetapi Belakangan ini, agama adalah sebuah Nama yang terkesan membuat gentar,menakutkan,dan mencemaskan. Agama ditangan para pemeluknya sering tampil dengan wajah kekerasan.fenomena yang juga terjadi saat ini adalah muncul dan berkembangnya tingkat kekerasan yang membawa -bawa nama agama (mengatasnamakan agama) sehingga realitas kehidupan beragama yang muncul adalah saling curiga mencurigai, saling mencurigai akan berdampak ketidakharmonisan toleransi agama merupakan jalan terbaik bagi terciptanya kerukunan antar umat beragama.

Toleransi dalam beragama bukan berarti kita hari ini boleh bebas menganut agama tertentu dan esok hari kita menganut agama lain atau dengan bebasnya mengikuti ibadah dan ritualitas 
semua agama tanpa adanya peraturan mengikat. Akan tetapi, toleransi beragama harus dipahami sebagai bentuk pengakuan kita akan adanya agama - agama lain selain agama kita dengan segala bentuk sistem,tata cara peribadatannya dan memberikan kebebasan untuk menjalankan keyakinan agama masing-masing . kebebasan dan toleransi merupakan dua hal yang sering kali dipertentangkan dalam kehidupan manusia, secara khusus dalam komunitas yang beragama .persoalan tersebut menjadi pelik ketika dibicarakan dalam wilayah agama.kebebasan beragama dianggap sebagai sesuatu yang mengahambat kerukunan (tidak andanya toleransi, karena dalam pelaksanaan kebebasan, mustahil seseorang tidak menyentuh kenyamanan orang lain. Akibatnya, pelaksanaan kebebasan menghambat jalannya kerukunan antar umat beragama. Demikian juga sebaliknya upaya untuk merukunkan umat beragama dengan menekankan toleransi seringkali dicurigai sebagai usaha untuk membatasi hak kebebasan orang lain. Toleransi dianggap sebagai alat pasung kebebasan beragama.kebebasan agama pada hakikatnya adalah dasar bagi terciptanya kerukunan antarumat beragama .tanpa kebebasan beragama tidak mungkin ada kerukunan antarumat beragama.Demikian juga,sebaliknya toleransi antarumat beragama adalah cara agar kebebasan Beragama dapat terlindungi dengan baik.

\section{Kasus/Masalah}

Dari latar belakang yang dapat dirumuskan Masalah-Masalah sebagai berikut:

kebebasan dan toleransi merupakan dua hal yang sering kali dipertentangkan dalam kehidupan manusia, secara khusus dalam komunitas yang beragam .persoalan tersebut menjadi pelik ketika dibicarakan dalam wilayah agama.kebebasan beragama dianggap sebagai sesuatu yang mengahambat kerukunan (tidak andanya toleransi, karena dalam pelaksanaan kebebasan, mustahil seseorang tidak menyentuh kenyamanan orang lain. Akibatnya, pelaksanaan kebebasan menghambat jalannya kerukunan antar umat beragama. Demikian juga sebaliknya upaya untuk merukunkan umat beragama dengan menekankan toleransi seringkali dicurigai sebagai usaha untuk membatasi hak kebebasan orang lain.

\section{Tinjaun Pustaka}

Persatuan dan kesatuan bangsa Indonesia adalah persatuan bangsa yang mendiami wilayah Indonesia , persatuan ini didorong untuk mencapai kehidupan yang bebas dalam wadah Negara yang merdekan dan berdaulat ,kesatuan bangsa Indonesia yang kita rasakan saat ini, itu terjadi dalam proses yang dinamis dan berlangsung lama ,karena persatuan dan kesatuan bangsa terbentuk dari proses yang tumbuh dari unsur-unsur social budaya masyarakat dan toleransi beragama sendiri.

Dalam kamus umum Bahasa Indonesia ,Toleransi berasal dari kata Toleran (inggris:Tolerance;arab :tassamuh) yang berarti batas ukur untuk penambahan atau pengurangan yang masih diperbolehkan .secara etimologi ,toleransi adalah kesabaran, 
ketahanan emosional, dan kelapangan dada.sedangkan menurut (Terminology )Toleransi yaitu bersifat menenggang (menghargai, membiarkan ,membolehkan) pendirian (pendapat pandangan ,kepercayaan,kebiasaan,dan sebagainya) yang berbeda dan atau yang bertentangan dengan pendirinya. Jadi sikap toleransi beragama adalah sikap sabar dan menahan diri untuk tidak mengganggu dan tidak melecehkan agama atau sistem keyakinan dan ibadah penganut agama -agama lain

Toleransi dalam Beragama memiliki pengertian yaitu tindakan saling menghargai antar umat beragama. tidak peduli apapun agama yang dianut, antar masyarakat harus saling menghargai. Toleransi antar umat beragama merupakan hal yang penting untuk dimiliki setiap orang di saat ini. Apabila setiap orang mempunyai sikap toleransi yang tinggi maka ini akan meminimalisir terjadinya konflik antar umat beragama, dan kehidupan antar umat beragama pun akan hidup dengan tentram dan damai ,maka dari itu,sangatlah penting untuk menerapkan sikap toleransi dengan umat beragama lainnya.

\section{Pembahasan.}

Persatuan dan kesatuan terdapat jelas dalam sila ke -3 pancasila yang berbunyi "persatuan Indonesia"persatuan Indonesia dalam pancasila berarti bahwa bangsa Indonesia tidak boleh terpecah dan harus terus bersatu. Indonesia terdiri dari ras,suku,agama,budaya,etnik,dan karaktek yang berbeda dari setiap wilayah,prinsip kesatuan dan persatuan ini sangat penting dimiliki untuk menjaga kekuatan dan keutuhan bangsa,ada beberapa prinsip persatuan dan kesatuan bagi bangsa Indonesia adalah Bhinneka tunggal ika ,nasionalisme, kebebasan yang bertanggungjawab dan sikap toleransi ,dalam mempertahankan kesatuan dibutuhkan alat pemersatu bangsa yang bias mempertahankan dan memperkuat kesatuan ,alat pemersatu bangsa ini biasa digunakan semua warga Negara untuk mempekuat persatuan bangsa.berikut alat pemersatu bangsa : dasar Negara pancasila,bendera kebangsaan yaitu bendera merah putih,bahasa persatuan yaitu bahasa Indonesia,lambang Negara yaitu burung garuda,lagu kebangsaan yaitu Indonesia raya.

Indonesia terdiri dari berbagai macam suku, bahasa, budaya, agama, dan lain sebagainya. jika fakta keberagaman tersebut dibiarkan atau malah dibenturkan maka akan menjadi sumber kehancuran dan kesengsaraan bagi masyarakat Indonesia. Untuk itu, semua komponen bangsa ini harus terlibat aktif untuk mengelola keragaman tersebut, dengan cara menanamkan kepada setiap individu dan kelompok akan pentingnya rasa toleransi dan saling menghargai. Toleransi adalah istilah untuk sebuah sikap menahan diri dari hal-hal yang negatif. Jika dikaitkan dengan perbedaan pendapat dan keyakinan, maka toleransi adalah sikap menahan diri untuk tidak menggunakan cara-cara negatif dalam menyikapi pendapat dan keyakinan yang berbeda. Jadi toleransi adalah sikap lapang dada terhadap prinsip orang lain, tidak berarti seseorang harus mengorbankan kepercayaan atau prinsip yang dianutnya melainkan harus tercermin sikap yang kuat atau istiqamah untuk memegangi keyakinan atau pendapatnya sendiri.

Salah satu komponen bangsa yang dapat mengambil peran penanaman dan pengembangan 
toleransi antar umat beragama yaitu lembaga-lembaga keagamaan, sebab dengan perangkatnya diyakini lembaga-lembaga keagamaan akan sangat mampu untuk menanamkan nilai-nilai toleransi kepada umatnya sehingga akan terbangun suasana kehidupan antar umat beragama yang harmonis. Lembaga keagamaan merupakan organisasi yang bertujuan mengembangkan dan membina kehidupan beragama, atau organisasi yang dibentuk oleh umat beragama dengan maksud untuk memajukan kepentingan keagamaan umat yang bersangkutan di dalam kehidupan bermasyarakat, berbangsa dan bernegara, yang tujuannya adalah untuk meningkatkan kualitas hidup keagamaan masing-masing umat beragama. Peningkatan kualitas keagamaan ini bisa bermakna lahirnya kesadaran toleransi pada masing-masing umat beragama, sehingga kemudian dapat berkontribusi bagi pembangunan bangsa. Modal sosial dan spiritual secara sederhana dapat diartikan adalah sebuah dorongan atau support dari semua umat beragama. Adapun bentuk dorongan yang paling sederhana dari umat beragama terhadap pembangunan bangsa yaitu menciptakan suasana yang rukun dan damai. Suasana rukun dan damai tersebut akan menjadi kenyataan manakala umat beragama memiliki toleransi.

\section{Kesimpulan}

Indonesia terdiri dari ras,suku,agama,budaya,etnik,dan karaktek yang berbeda dari setiap wilayah,prinsip kesatuan dan persatuan ini sangat penting dimiliki untuk menjaga kekuatan dan keutuhan bangsa,ada beberapa prinsip persatuan dan kesatuan bagi bangsa Indonesia adalah Bhinneka tunggal ika,nasionalisme,kebebasan yang bertangjawab dan sikap toleransi ,dalam mempertahankan kesatuan dibutuhkan alat pemersatu bangsa yang bisa mempertahankan dan memperkuat kesatuan alat pemersatu bangsa ini bisa digunakan semua warga Negara untuk mempekuat persatuan bangsa.berikut alat pemersatu bangsa : dasar Negara pancasila,bendera kebangsaan yaitu bendera merah putih,bahasa persatuan yaitu bahasa Indonesia,lambang Negara yaitu burung garuda,lagu kebangsaan yaitu Indonesia raya. Jika dikaitkan dengan perbedaan pendapat dan keyakinan, maka toleransi adalah sikap menahan diri untuk tidak menggunakan cara-cara negatif dalam menyikapi pendapat dan keyakinan yang berbeda. Adapun bentuk dorongan yang paling sederhana dari umat beragama terhadap pembangunan bangsa yaitu menciptakan suasana yang rukun dan damai.

\section{Daftar pustaka}

Ruslan, I. (2020). Kontribusi Lembaga-Lembaga Keagamaan dalam Pengembangan Toleransi Antar Umat Beragama di Indonesia. Arjasa Pratama.

https://scholar.google.co.id/scholar?hl=id\&as_sdt=0,5\&qsp=1\&q=toleransi+antarumat+kesa tuan+bangsa\&qst=br\#d=gs_qabs\&u=\%23p\%3DCymHWFGUYIUJ

Siyoto, S., \& Sodik, M. A. (2015). Dasar metodologi penelitian. Literasi Media Publishing.

https://scholar.google.co.id/scholar?hl=id\&as_sdt=0\%2C5\&q=muhammad+ali+sodik\&oq=\# d=gs_qabs\&u=\%23p\%3DjGF7Wz2n5JkJ 
Devi, D. A. (2020). Toleransi Beragama. Alprin

https://scholar.google.co.id/scholar?hl=id\&as_sdt=0\%2C5\&q=persatuan+kesatuan+tolerans i\&btnG=\#d=gs_qabs\&u=\%23p\%3DYRoLYGnbLUgJ

Makna, B. A. Pengertian Persatuan dan Kesatuan Bangsa.

https://scholar.google.co.id/scholar?hl=id\&as_sdt=0\%2C5\&q=pengertian+kesatuan+dan+pe rsatuan\&oq=\#d=gs_qabs\&u=\%23p\%3DUhcnN_3DMuwJ

Ruslan, I. (2020). Kontribusi Lembaga-Lembaga Keagamaan dalam Pengembangan Toleransi Antar Umat Beragama di Indonesia. Arjasa Pratama.

https://scholar.google.co.id/scholar?hl=id\&as_sdt=0\%2C5\&q=toleransi+antar+umat+beraga ma\&o=toleransi+antar+\#d=gs_qabs\&u=\%23p\%3DCymHWFGUYIUJ 